\title{
Modern Communication Devices in the General Aviation Aircraft Maintenance
}

\author{
Ing. Martin Novák, Ph.D. \\ Department of Air Transport \\ CTU in Prague, Faculty of Transportation Sciences \\ Prague, Czech Republic \\ novakm@fd.cvut.cz
}

\author{
Mgr. Iveta Kameníková \\ Department of Air Transport \\ CTU in Prague, Faculty of Transportation Sciences \\ Prague, Czech Republic \\ kamenive@fd.cvut.cz
}

\author{
Ing. Jan Podhadský \\ Department of Air Transport \\ CTU in Prague, Faculty of Transportation Sciences \\ Prague, Czech Republic \\ podhajan@fd.cvut.cz
}

\begin{abstract}
The purpose of this article is to design a software that enables an integration of modern communication devices in the process of general aviation aircraft maintenance. The theoretical part deals with the legislative requirements of both maintenance and management processes for continuing airworthiness. The practical part focusses on software design and automation of the processes. An important part of the article is a chapter about economic evaluation based on the proposal of the solution.
\end{abstract}

Keywords - aircraft maintenance, continuing airworthiness management organization, approved maintenance organization, software, user, overhaul, scheduled maintenance

\section{INTRODUCTION}

The general aviation has noticed considerable development in the recent years. Together with the development of the general aviation air traffic goes the increase of the maintenance. Every single revision has a big administrative workload on a staff. Doing the administrative tasks oppresses employees responsible for correctly performed scheduled maintenance as well as employees responsible for the continuing airworthiness. Proper implementation of the scheduled maintenance at set intervals and continuing airworthiness is also important for the safety of the air traffic. There is no software on the market, which would cover all needs of general aviation maintenance organization right now.

This study deals with the involvement of the modern communication devices into aircraft maintenance processes, thereby reducing the administrative workload on the employees and increasing the safety of the air traffic. To involve the modern communication devices into the general aviation aircraft maintenance it is necessary to develop specialized software which would allow this involvement.
The main purpose of this study is to design the required software, to describe functions of the program and to create a user friendly interface. Functions of this program include continuing airworthiness management, performance of the scheduled maintenance and collecting of the required flight data for proper management of the maintenance system.

\section{ACTUAL CONDITION}

Before designing the software it was necessary to study the legislative requirements for the management of the continuing airworthiness and to analyse current software equipment of the maintenance organization and of the organizations approved for continuing airworthiness management. Based on these two initial steps we have started to design the program.

\section{A. Legislative framework of the continuing airworthiness management}

The legislative framework of the continuing airworthiness management in the Czech Republic consists of:

- Law No. 49/1997 Coll. Civil aviation and amending and supplementing law No. 455/1991 Coll., on business, as amended;

- Regulation of the European parliament and of the Council;

- National aviation regulations [2];

- Directive of the Technical division of the Civil Aviation Authority [3].

\section{B. Current software equipment}

\section{1) Approved maintenance organization (AMO)}

There is no commercially available specialized software in the general aviation maintenance organizations today used to 
automate the creation of service documentation, certification of the performed maintenance and evidence of already performed inspections. The software used in the approved maintenance organizations was in most cases made on request specifically for the needs of the particular company. In organizations approved to the aircraft maintenance with 1 to 10 aircraft are all the administrative activities carried out manually with the help of the MS Office tools which means significant time requirements and administrative workload for the employees [1].

\section{2) Continuing approved maintenance organization (CAMO)}

Processes and activities carried out by the continuing approved maintenance organization are more time and administrative consuming. Because of this there are bigger requirements for the software used to manage the activities of the organization.

The CAMO of the general aviation, which manage the airworthiness of fewer aircraft (usually $1-10$ ) and to $5700 \mathrm{~kg}$ MTOM, primary use MS Office tools package. These tools stand out for their simplicity but provide a minimum level of the automation. Another option is to use software created by the companies themselves or designed by other company specifically for the needs of the maintenance organization. The last option is to purchase specialized commercial software. But due to the high cost it is not used in the CAMO in the general aviation [1].

\section{PROGRAM PLATFORM}

\section{A. The activities and procesess in the maintenance}

organization from a legislative point of view

Before the program design it was necessary to describe the activities and processes of the organization authorized to manage the continuing airworthiness in concordance with Section A, Subpart G of Annex I (Part M) of Commission Regulation No. 1321/2014. The goal of these activities is to ensure managed aircraft ever meet applicable airworthiness requirements.

The mission of the CAMO is to ensure:

- making of all aircraft maintenance in concordance with the approved maintenance program;

- $\quad$ elimination of all defects and damages affecting safe operation;

- $\quad$ making of all applicable airworthiness directives (AD)

- changes of maintenance program resulting from airworthiness directives;

- establishing principles for non-mandatory modifications and inspections;

- making of airworthiness review;

- $\quad$ releasing of permits to fly. [3]

\section{B. Program design}

The designed program consists five main parts. The proposal of the design was that the program functions cover all needs of organization managing the continuing airworthiness and maintenance organization. In the design we have gone from simple to more complex parts. An important element of the program is the involvement of the modern communication devices which can be used both as devices for displaying the values but also as a tool for inserting data into the program.

The five main parts of the program are:

- $\quad$ Service;

- $\quad$ Fluids;

- Stock;

- Finance;

- Collection of flight data.

We have tried to design the most user friendly program and with maximum acceptable level of the automation in performing activities and processes.

\section{1) Service}

The most important and the most extensive part of the program. It contains information for the proper management of the CAMO and the proper performance of the inspections in a service organization. The service part of the program is devided into:

- Overview;

- Maintenance;

- Maintenance programs;

- Staff.

We performed this distribution to separate the information about the current status of a particular aircraft away from the processes related to the maintenance and from the storage of additional instructions for the continuing airworthiness.

a) Overview - it saves detailed information about specific aircraft. It archives dates of the performed scheduled maintenance, records of the performed additional instructions for continuing airworthiness and records total aircraft flight hours. At the same time it alert the user about the term of these inspections and overhauls. Finally keeps information about all limited-life parts installed at the aircraft.

b) Maintenance - the main communication interface for storing data related to the individual performed inspections of aircraft compliance with the airworthiness directive and an information of worked hours for each employee. The data stored here is used in other parts of the program.

c) Maintenance programs - it allows the user to save all additional instructions for continued airworthiness and accompanying technical documentation into the system. The instructions stored here are assigned to a specific aircraft. 
d) Staff-database of all personnel in the company which also serves as a tool for setting user rights of individual employees for handling the program.

\section{2) Fluids}

This section is primarily designed for recording stocks of the operating fluids used in the company. Another function of this part of the program is to enter distribution and sale of various kinds of the operating fluids. This step ensures that the displayed amount of the inventory is still up-to-date. The data stored in this section is further processed in "Finance".

3) Stock

The third part of the program was designed for economy of the company. Due to the large consumption of spare parts during regular inspections, an up-to-date overview of the status of each item must be kept.

This section is designed as an overview, because the consumed parts are entered in the "Maintenance" and newly added components are saved to the system in the "Finance".

\section{4) Finance}

In this section of the program there are processed the data saved in the previous sections. This data is used to create all invoices for the operations performed in the company and to pay salary of each employee. There are also entered the data on the newly supplied operating fluids and the spare parts.

Overall, this part is used to handle the financial management of the company. This is a very responsible action and may be carried out only by the employees which have appropriate permission to such activities.
For this reason, the system is secured by usernames and passwords assigned to individual users.

\section{ECONOMIC EVALUATION}

After designing we set three variants of the realization of the program in functional form and we compared the advantages and disadvantages of each variant:

- the company deals with creating custom software [4];

- $\quad$ independent programmer;

- $\quad$ student's project.

The choice of the variant of the software depends mainly on how much money the customer is willing to release. Other factors influencing the choice include the ability of the customer to be involved in the formation of the final program and providing technical support even after the completion of the program. A summary of the options with price valuation is presented in Table 1

For our purposes we have chosen the second of the listed options. We decided to prepare a design of the program with self-help and final implementation entrusted to the hands of the programmer. We have chosen this option primarily because of the low costs of the actual implementation of the program.

Our chosen option also provides technical support after completion and delivery of the software to the final customer.

TABLE $1-$ SUMMARY OF THE OPTIONS

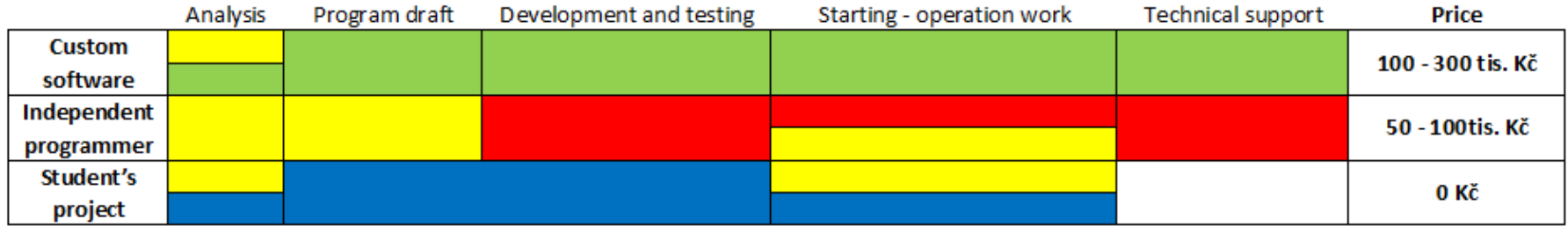

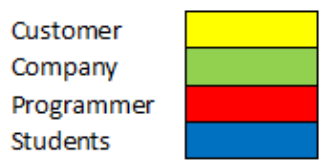

5) Collection of flight data

The last part of the program deals with facilitating the collection of flight data and their maximum update. The flight data for the needs of the program includes a number of flying hours and number of landings of each aircraft. To collect the flight data the modern the communication devices are primarily used.

The flight data are the most important information for the system management of the continuing airworthiness of the aircraft. Because of this, it is necessary to ensure the correctness and updates of the data saved in the system. In the design specifications of the data collection we also thought of the security of the whole process, because any tampering with the data would undermine the entire system.

\section{CONCLUSION}

The goal of our work was to create a software that would allow the integration of the modern communication devices in the process of maintaining the general aviation aircraft thus reducing the administrative workload of the employees.

In our opinion, the program established under this proposal will contribute to the development of general aviation aircraft maintenance. It is done by both accelerating and facilitating administrative processes as well as by introducing modern elements to this often neglected sector of the general aviation. 


\section{REFERENCES}

[1] Rashman, Josef. Software tools for the managemet of the continuing airworthiness. Prague, 2013. Bachelor thesis. Czech Technical University in Prague Faculty of Transport.

[2] Air regulations, the Civil Aviation Authority [online]. 2011 [cit. 17.04.2014]. Available from: http://www.caa.cz/predpisy/leteckepredpisy

[3] Directive CAA. The Civil Aviation Authority [online]. 2011 [cit. 17.04.2014]. Available from: http://www.caa.cz/predpisy/smernice-ucl.

[4] Software na míru. VitSoft S.R.O. Sowtware na míru [online]. 2010 [cit. 14.04.2014]. Available from: http://www.software-na-miru.cz/\#kdyzvolit-reseni-softwaru-na-miru
[5] Endrizalová, E. - Mrva, P.: Optimization of processes of aircraft ground handling. In 1. vedecká konferencia doktorandov: zborník príspevkov. Košice: Technická Univerzita, 2011, s. 113-119. ISBN 978-80-553-06650. (in Slovak).

[6] Hrůza, P. - Soušek, R. - Szabo, S.: Cyber-attacks and attack protection. In Proceedings of the 18th Word Multi-Conference on Systemics, Cybernetics and Informatics. Orlando, Florida: International Institute of Informatics and Systemics, 2014, p. 170-174. ISBN 978-1-941763-04-9.

[7] Němec, V.: Program of Human Factors in Technology Aircraft Manintenace. In Nové trendy v civilním letectví 2006 - Sborník příspěvků mezinárodního odborného semináře. Brno: VUT v Brně, Fakulta strojního inženýrství, 2006, s. 103-108. ISBN 80-7204-450-8. (in Czech).

[8] Hospodka, J.: External Costs of Air Transport. In Workshop 2010. Praha: České vysoké učení technické v Praze, 2010, p. 404-405. ISBN 978-8001-04513-8 